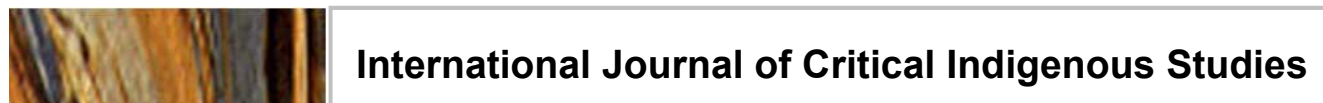

Volume 6, Number 2, 2013

\title{
Māori Identity Construction in SNS
}

\section{Acushla Dee O'Carroll PhD candidate, Massey University}

\begin{abstract}
Māori people (the Indigenous people of New Zealand) possess deep spiritual connections to the environment, landscape and seascape which can be markers of one's identity and acknowledging where their ancestors came from and thus, where they come from. Traditionally, ones whakapapa (genealogy), language and knowledge were acquired within traditional spaces (such as the marae) and orally passed down through generations. These aspects of cultural are no longer restricted to oral traditions or to the marae space. An increased access to knowledge and information through the Internet and SNS (social networking sites) now provides alternative methods to finding out, learning more and engaging with aspects of Māori cultural identity. This paper will address notions of Māori cultural identity in ascertaining how Māori identity is formed and constructed using SNS.
\end{abstract}

\section{Introduction}

Many scholars have theorised Māori cultural identity (Māori identity) and what it means to be Māori in Aotearoa and beyond (Hiroa 1982; Rangihau 1977; Durie 1995b; Mclntosh 2005; Borell 2005; Moeke-Pickering 1996; Westling 2007; Mckinley et al. 1992; Durie 1995a; Matthews and Jenkins 1999; Wyche et al. 2013; Te Hiwi 2008). Prior to European contact, identity was demarcated through tribal groupings and through affiliations to iwi (tribe), hapū (sub-tribe) and geographical configurations (including regional dialectal differences). Māori as a word or concept can trace its initial origins to meaning 'normal', or 'regular' (Williams 2006), and before European contact did not act to categorise or identify Māori, as Māori. Māori identity itself began to develop after European contact (Durie 1998). This positioning of Māori as normal and the new arrivals as the other has now been reversed, resulting in considerable discussion and debate about the nature of Māori and Māori identity (Durie 1997; Moewaka Barnes 2000; Walker 2004). Latterly, multiple influences are influencing Māori identity as mass media and especially new technologies associated with the internet make their presence felt (Niezen 2005).

What is clear from these dynamics is that Māori identity is fluid and can mean different things for different people. This paper will review existing literatures around Māori identity and use these understandings as a foundation for presentation of data on social networking sites (SNS) use among young Māori to highlight dimensions of sense of self and community. Māori media and Indigenous identity will also be briefly discussed as part of the framing for this paper.

\section{Aotearoa New Zealand context}

To describe the Aotearoa New Zealand context and in particular, the state of the Māori nation, is to acknowledge the histories of Māori people and culture and necessary context to exploration of contemporary identity. 
The Indigenous people of Aotearoa New Zealand, the Māori, remain a colonised people, as a result of British incursions in the mid-19 ${ }^{\text {th }}$ century (Durie 1995; Orange 2011; Walker 2004). In spite of provisions agreed to in the nation's founding document Te Tiriti o Waitangi (Treaty of Waitangi), colonisation had severe effects on Māori/settler relationships. The colonists worked to subjugate, marginalise, and discriminate against Māori. Land alienation and warfare resulted in major loss of life and resources, with profound impacts on Māori systems, values, and ways of knowing and being (Kawharu 1989; Biggs 1989; Benton 1987).

Despite injustice and oppression, Māori culture and communities have survived and, in some respects, are resurgent with economic, cultural, artistic, sporting, and political development to the fore. Māori cultural identity has endured colonisation and imperfect race relations and is being expressed in many different forms and contexts. Aspects of Māori cultural identity are nationally and locally celebrated during national days, festivals, special events, and functions across the country and have become an economic drawcard for tourism in New Zealand.

\section{What is Māori identity?}

Whakapapa - genealogy

Māori scholars discuss identity as made up of interlinked strands which can broadly be described as ancestry and cultural practices (Moeke-Pickering 1996). In practical terms these two aspects of Māori identity are interwoven and overlapping. Ancestry argues that Māori identity is based on kinship to iwi, who trace their genealogy to a common ancestor (Durie 1997; Gibbons et al. 1994; Te Rangi Hiroa 1982; Walker 1992), "Whakapapa provides our identity within a tribal structure and later in life gives an individual the right to say, 'I am a Māori'” (Mead 2003, 42). Moeke-Pickering (1996) describes how Māori ancestry, structures and practices have played a key role in the continuity of Māori identity.

However, identity is not only about whakapapa, it is an articulation of the individual and is often guided by the teachings within whānau (family) and extended whānau during upbringing (Kāretu 1990). Hence the second dimension, cultural practices (or ethnicity as articulated by Kukutai (2004)), encompasses knowledge of customs, practices, language, kawa (customs), and tikanga as well as involvement with iwi, hapū, and/or marae structures, as related to Māori identity (Kāretu 1993; Rangihau 1977). Self-identified Māori identity is also discussed in the literature as being a form of asserting identity through engagement, participation, and/or awareness in aspects of Māori culture (such as the language, customs, knowledge). Durie (1997) goes on to say that whakapapa is the primary indicator of Māori identity, and engaging with cultural practices strengthens that person's identity (such as knowledge in customs, competence in the language).

In contrast, negative slurs and racism towards Māori identity can have implications on people's personal identity and how they perceive their own cultural identity. Māori statistics around unemployment, imprisonment, violence, criminal behaviour, and poor education have, for some people, become markers of Māori identity. While these statistics and racial stereotypes might be realities for some Māori, for others, they represent a negative idea of Māori cultural identity. These realities can have major implications for Māori and can cause resentment towards being Māori or expressing Māori identity. Identity therefore, is a choice and while it is conferred by membership into the group, it is more importantly chosen by the individual (Kukutai 2004). 


\section{Tūrangawaewae}

Tūrangawaewae, in its strictest application, refers to those places to which one has allegiance and a 'right to stand'. In a wider sense, it embraces a person's identity as a Māori - culturally, linguistically and emotionally (Kāretu 1990, 112).

Natural environments, that is, lands, mountains, and waterways, have been considered to be deeply entrenched in Māori identity (Tomlins-Jahnke 2002). The inextricable connection to the land and water is founded on spiritual dimensions where respect and guardianship are practised (Rangihau 1977; Walker 2004) in relation to salient elements of the landscape. The major impacts of colonisation on Māori and iwi/hapū identity in a geographical sense, have been significant (Robson and Reid 2001). Pepper-potting and urbanisation of Māori moving away from tribal lands (into largely populated cities), coupled with land loss and confiscation by the Crown, has equally impacted on a sense of Māori identity (Mclntosh 2005).

\section{Te Reo Māori}

Building on Moeke-Pickering's idea of engagement with cultural practices as Māori identity is te reo Māori. A level of proficiency in te reo Māori as an imperative marker of Māori identity was asserted by the late Sir Apirana Ngata and later reinforced by Timoti Kāretu, "Ki te kore e mōhio ki te kōrero Māori, ehara koe i te Māori, if you do not speak Māori, you are not Māori" $(1993,223)$. These sentiments resonated with some Māori, prompting a form of cultural resurgence and revitalisation.

We became driven by a desire to 'be able to be Māori', to speak Māori, to understand and practice Māori cultural ways of knowing and doing. To that end, we attended Māori language classes at night, community driven Māori cultural studies in weekends and kōhanga reo [pre-school language institution] during the day (Morehu 2009, 5)

Kāretu eloquently states his position on the language as being at the forefront of his identity and is thus a part of his tūrangawaewae (place of standing and belonging). Without the language, much of the old ways of knowing and doing will be lost, "for me, language is an intrinsic part of my tūrangawaewae. It is an essential element of all that I hold dear - the rites of passage of Māoridom will pale into insignificance and ignominy without it" (Karetu 1990, 116). Thus, for some Māori, having some proficiency in te reo Māori is the key to opening up the metaphorical door to the Māori world of understanding and being.

For others, te reo Māori proficiency may not be a marker of their cultural identity, "establishing a 'secure' Māori identity based solely on particular criteria of Māori culture (te reo Māori, tikanga, marae, etc...) continues to be problematic for some Māori" (Borell 2005, 2). Not having a level of proficiency in te reo Māori may be judged by some as inauthentic or not genuinely Māori (which echoes the earlier sentiments of Apirana Ngata), "Those who are not seen as connected in this way are often defined by what they are seen as lacking, hence terms such as disconnected, distanced, detached and dissociated" (Borell 2005, 2).

Such judgements are described by Gibson $(1999,54)$ as having the potential of impacting severely on one's life in ways that might not be felt or experienced until later on in life. Gibson's study revealed that whakapapa was the most pertinent marker of Māori identity for her participants, and that having te reo Māori proficiency or any prescribed characteristic attributed to being a 'real' Māori was not what they deemed as important or central to their identity. Further research by Ngaha (2011) looked at the relationship between identity and e reo Māori and how the importance of language revitalisation and continuation depends on the number of speakers of the language. The study, in particular, found that despite the 
decrease in numbers of speakers of te reo Māori, there was no evidence suggesting that te reo Māori was not central to Māori identity and that instead, through the learning and use of te reo Māori, Māori identity was strengthened.

There are various underpinning principles to Māori identity. According to the literature, Māori identity is thus determined by two main factors; whakapapa and self-identification. Without whakapapa, there can be no claim to being Māori, it is an essential and imperative part of Māori identity. Māori identity is therefore affirmed by family members, hapū, and iwi members through the validity of your whakapapa and as part of that community. It is also self-proclaimed and identified by the individual themselves, which is where markers of Māori identity such as te reo Māori proficiency and knowledge of tikanga might be of significance and might therefore be used as part of one's Māori identity, however they are not essential to Māori identity.

Māori identity is therefore fluid and dynamic as articulated by Mclntosh (2001, 142): "To be Māori is to be part of a collective but heterogeneous identity, one that is enduring but ever in a state of flux." This state of flux is determined by the individual and his or her environment, surrounds, and priorities at the time, and of what is important to them and who they are. Mclntosh refers to this flux as being something that is not fixed or set in concrete. Identity evolves and changes as time and priorities change and tend to reflect what's important to the individual.

\section{Māori identity framework}

A number of identity markers were drawn from Te Hoe Nukuroa (THNR) as my thematic analytical frame that are based on main themes identified through the data. THNR is a longitudinal study set up in 1992 to "enable cultural, social, economic and personal factors to be correlated" (Durie 1995, 461). The study consisted of approximately 700 households and 1200 participants. Its framework featured four major axes in which Māori cultural identity was measured, including 'Te Ao Māori' (The Māori World). This axis features the following distinct cultural markers of Māori identity: ethnic affiliation; language and tikanga (practices); land, fisheries and forests (environment); marae (common gathering place) and hapū activities; and iwi links.

The framework was constructed as a tool to conceptualise current social, cultural, and economic positions of Māori, recognising that Māori are diverse and dynamic with multiple affiliations. The framework attempted to address ideas of Māori identity from both traditional and contemporary points of view, attempting to avoid prescribing parameters as to what Māori identity might be. However, there remains to be concerns about the THNR framework being used as a measurement tool of Māori identity as being prescriptive and homogenising Māori identity and what it means to be Māori (Stevenson 2004).

THNR as a framework was selected for this study as its cultural markers echoed a combination of both customary and contemporary values that reflect potential aspects of Māori identity, the same cultural markers that were prevalent in the dataset as being important to Māori identity for research participants. Those key elements included whakapapa (genealogy), te reo Māori (Māori language), kapa haka (performing arts), and tūrangawaewae (place of belonging). While in no sense definitive of Māori identity, nevertheless they do provide a sense of some of the more commonly discussed cultural boundaries.

For this paper both the subsets and units of inquiry of the THNR framework are drawn upon in discussion of ways in which participants spoke of using SNS to express, engage with, and learn more about aspects of their individual and collective Māori cultural identities. 


\section{Māori media}

Māori have traditionally been early and rapid adopters of new technologies. Māori adopted literacy at a rapid pace, and later used these skills for letter writing, which were often formal, and in te reo Māori (Spolsky 2003). With increasing literacy, Māori newspapers began printing commentaries and opinion pieces on politics and oral histories, formal whaikōrero and Māori activities, international news and accounts (McRae 1997). As part of the WAI11 Waitangi Tribunal report, the claim supported that the Māori language be recognised as a taonga under protection of the principles of Te Tiriti o Waitangi, and broadcasting rights were deemed to be one of the pathways through which to revitalise the declining Māori language. 21 radio stations (frequencies and resources) were set aside and allocated for iwi-based promotion of the language with the first station, Te Üpoko o te Ika FM 1161, being aired in 1988 (Matamua 2006). Māori Television Service (MTS) was launched in 2004 with the aim to promote te reo and Māori culture (Anon 2003). Later in 2008, the Te Reo Māori channel was launched where programmes using only te reo Māori content were aired. Smith and Abel (2008, p.9) examine the emergence of Māori Television and its role and function through assessing the channel's ability to present counter-narratives of New Zealand national identity as a way to decolonise the mind and "shift the default setting of New Zealand media-scapes from one that privileges a settlercentric purview".

The Internet became a rapidly adopted technology by Māori for multiple reasons. These reasons included increased access to information and learning opportunities; the ability to create a Māori voice; collaboration with other Indigenous communities; language revitalisation; and sharing of specialised knowledge within groups. A number of specialised studies have focused on Māori use of Internet and the benefits and risks attached to Internet use (Muhamad-Brandner 2010; Smith and Sullivan 1996; Keegan 2000; Lemon 2001; Sheehan 2011; Pewhairangi 2002). Further work on social network analysis amongst Māori networks and identities has been done by Kennedy (2010). Māori are now transitioning to the virtual space where research shows that $86 \%$ of Māori are using the Internet (Smith et al. 2011). Goodwin (2011) discusses Māori cultural identity and social media platforms such as Facebook as a "space of becoming" of which users gain greater control over their discourses linked to the construction of their identity, both collectively and individually.

\section{SNS and indigenous identity}

Niezen $(2005,51)$ discusses the positives of how indigenous peoples are using the Internet to make it more possible to "express abstract identity" within an online discourse between Indigenous peoples who are oppressed and use the Internet as a space to assert their cultural identity as a "cultural reawakening and boundary reinforcement". This online arena of interaction and engagement between members of Indigenous groups provides a platform for Indigenous empowerment and application of cultural knowledge, experiences, and ideas.

Internationally, Indigenous peoples are using the online arena as a platform to assert and promote cultural identity against the dominant discourse, societies, and globalisation (Diamandaki 2003). However, it must be noted that SNS users must contend and conform to the architecture (and all of its limitations and restrictions) of the space and how it is structured, including privacy issues and the mining of users' data (Hoadley et al. 2009; Acquisti and Gross 2006; Jones and Soltren 2005).

This paper explores notions of Māori identity and applies a set of cultural markers used in a Māori identity measurement framework in ascertaining how Māori users of SNS (both located within Aotearoa New Zealand and abroad) are using SNS to access, engage with, and learn about aspects of individual and collective Māori identity. 


\section{Method}

The framework I used to conduct the research for this paper encompasses kaupapa Māori principles that provide a platform for Māori research to be conducted using Māori cultural practices and a Māori worldview (Bishop 1996; Cram 1992; Moewaka Barnes 2008; G. H. Smith 1997; L. T. Smith 1999). Additionally, the framework is informed by my tribal upbringing, which contributes greatly to the way I, as a researcher, interpret and make meaning. A Taranaki-centred focus that derives from the prophetic teachings of Te Whiti o Rongomai and Tohu Kākahi in their peaceful fight for freedom (Hohaia et al. 2001) are complementary to the framework which invoke notions of rangimārie and hūmārie (peace and good thoughts to all, tranquillity and humility). This unique way of seeing and understanding the world provides a cultural lens when analysing and making meaning of the data and findings. These influences are underpinned by the third component of the framework, which is te reo me ngā tikanga; the Māori language and protocols that enable a greater understanding of holistic Māori worldviews and philosophies. From within this threetiered framework, I conduct the research, data collection and analysis from a Māori perspective and using a Māori cultural lens to viewing and making meaning of the data.

The paper draws on a range of data sets, including focus groups that were conducted with rangatahi Māori aged 18-25, produced in the course of my doctoral studies ${ }^{1}$. Another data set involved two iwi (one based in London, UK and the other based in South Taranaki of Aotearoa New Zealand) iwi case studies. An interview schedule was designed to capture talk that generally pertained to five research questions of my doctoral thesis. Thematic analysis was employed in this paper for its inductive orientation (Boyatzis 1998; Braun and Clarke 2012; Attride-Stirling 2001) to the patterns and variations at work in the talk of participants. The data presented in the analysis is representative of the dataset collected by the researcher and is not intended to be representative of all Māori. Direct quotes were selected from themed data to represent the common and varying views expressed in the data with regards to the expression, articulation and construction of identity in social media.

\section{Analysis}

This section of the paper will draw from a range of Māori perspectives spanning generations (including rangatahi (youth) pahake (adults) and kaumātua (elders)) in understanding how SNS plays a role (if any) in the formation or construction of forms of Māori identity. Relevant cultural markers from Te Hoe Nukuroa Māori identity framework will be used to discuss how participants of this study use SNS for Māori identity formation and construction including whakapapa, te reo Māori, kapa haka (performing arts), ancestral connections and marae/hapū activities.

\section{Whakapapa}

The concept of whakapapa in Māori identity is crucial to Māori identity. Knowing genealogical links and connections to both people and environment is part of knowing how you connect and fit into the tapestry of genealogy. Rangatahi participants in this study discussed whakapapa information as being accessible through family pages or familyorientated pages, including marae, hapū, and iwi pages on Facebook.

\footnotetext{
${ }^{1}$ Doctoral thesis is entitled, Kanohi ki te kanohi (face to face), a thing of the past? An examination of social networking sites and its impacts on tikanga (practices), tuakiritanga (identity) and whanaungatanga (relationships).
} 
Participant response: Whakapapa

Yeah we use this page for people that are looking for their links. People looking for whakapapa and who they whakapapa to, who they whakapapa off

- Katarena, focus group participant

Physical dislocations from ones tūrangwaewae, marae or kaumātua who are expert in whakapapa make it difficult for people to access these sources of knowledge to learn their whakapapa. SNS fills the void and allows people to learn about their ancestry remotely.

A number of participants indicated that whakapapa shared in publicly accessible virtual spaces had its risks. The information might easily be used by unintended recipients, which caused participants to be cautious about how they shared this type of information and with whom.

\section{Participant response: Differing views on personal identity}

There was a thing whereby you don't put your whakapapa online, or it was more like you don't actually write it down. Um, I think that [attitude] is changing a lot more now and that people are much more accepting [to] put down your whakapapa online and those sort of fears are [...] changing I think for the better (personally)

- Ngāti Rānana case study participant

One participant (part of the Ngāti Rānana pan-tribal iwi in London, UK) comments on the fears that some people may have had with sharing such sacred knowledge in public spaces. There is certainly a level of consideration given to when, how and with whom whakapapa is shared. This participant noticed a change in how Māori society approaches the sharing (and making viewable to the public) of whakapapa and are increasingly becoming more accepting of online tools as ways to share this information.

Another participant spoke about her observations of many families that moved away from their tribal boundaries and struggled to return home again. This view was shared with other members of the same case study. New generations brought up away from their tūrangawaewae would seek whakapapa information through other means (internet, SNS, emails, ancestry databases).

\section{Participant response: Differing views on personal identity}

Where I fall short with that is, it's nice to connect the dots but then when it comes to, "Oh can you tell me who I am, can you tell me this, can you tell me that?" that's when I say well "Ok, here's the address, here's the time, here's the hui [meeting], hoki mai ki te kāinga [return home]

- Ngaruahine Rangi case study participant

For this particular marae, kaumātua were generally concerned that the numbers of people physically 'coming home' to participate in their cultural institutions and activities would diminish if knowledge and information such as whakapapa were shared in ways other than face to face.

An iwi organisation based in South Taranaki described how many descendants continued to opt for the face-to-face method of seeking whakapapa information, 
Participant response: Differing views on personal identity

When people want to look for their whakapapa, they don't use Facebook a lot of its coming directly into the office. Funny that aye. Their queries are coming straight to [organisation name] Hapū. And I find that interesting because of all the places that I would have thought, that they would participate at that level would be on Facebook

- Ngaruahine Rangi case study participant

Engaging with this type of information and knowledge can be a particularly sacred process, when dealing with lines of genealogy that might reveal concealed information that might not be public knowledge. Whakapapa was not just handed onto anybody, it was entrusted to those who had the right to it, and who could look after it. This remains to be the feeling for some Ngaruahine descendants and finding out this information at a face-to-face level shows a genuine willingness to want to learn about themselves.

Elders of my tribe consider whakapapa to be similar to that of DNA and the value we place on our DNA, which encompasses our genetic makeup, but also our identity of who we are and of whom we come from. These elders affirmed that whakapapa knowledge should be passed down orally, and not shared publically where anyone can access and use for their own purposes.

Te reo Māori

Interestingly, focus group and interview participants indicated that their use of te reo Māori on SNS was limited to responding to family and extended family members' posts in te reo Māori. Te reo Māori was not necessarily used with friends who were not conversant in the language, or used in general posts (in status updates) as friends within a participant's network might not understand them.

\begin{tabular}{|l|}
\hline Participant response: Te reo use in SNS \\
\hline Like oh man it's funny cos' all like my aunties and uncles and that are all \\
going on it [Facebook] and they all like speak te reo and so I've always... I \\
feel inclined that I've got to speak [type] to them in Māori yeah cos' they \\
usually always comment me in Māori so I just feel like I'm inclined to, I'm \\
obligated to reply in Māori [laughs] \\
- Kawena, focus group participant
\end{tabular}

A number of participants would use a few te reo Māori words in their posts but would not necessarily write extensively in te reo which could be because of capability or preference of language to use in social networks such as Facebook. Only one out of 55 focus group participants ${ }^{2}$ intensively used SNS to practise and learn te reo Māori and used it regularly on his own page and accessed Māori language group pages to learn and converse in te reo Māori (“Te Mana o te Reo Māori - Facebook page" 2012).

\footnotetext{
${ }^{2}$ Notably, te reo Māori was not part of the criteria for participants to be interviewed, thus this number is not representative of all Māori.
} 


\section{Kapa haka}

Kapa haka was an important identity marker in which participants felt that, through SNS, they could access kapa haka and engage with Māori performing arts, song, and te reo Māori. Some participants, particular in Ngāti Rānana, discussed how important SNS was for them to learn more about kapa haka, which might have been accessible to them offline.

Participant response: Kapa haka
When I first joined up with Ngāti Rānana to do all of the performances,
nothing was online and I think it does brush on that sort of aspect of the old
ways of learning which is um, you know kanohi ki te kanohi [face to face]
and so I've found it very, very hard to learn all of the kapa haka brackets
that we had because there was nothing online, but I've changed that kind
of mentality rightly or wrongly by putting a lot of our stuff [kapa haka
performances] online [...] [and] linking it in with the identity thing, I think it's
part of Māori identity
- Ngāti Rānana case study participant

Given that Ngāti Rānana is a pan-tribal iwi living abroad, their access to sources of knowledge in areas of kapa haka are obviously limited given their location. SNS and online video depositories are certainly filling the gap and enabling interested Māori (and non-Māori alike) to investigate and learn kapa haka from the Internet. As the participant discusses, he posted their Ngāti Rānana kapa haka videos in YouTube and linked that to having Māori identity, and particularly being so far from home, family and Māori institutions, these forums enable Māori to express their identity no matter where they are in the world.

\section{Ancestral connections}

In a Māori worldview, recitations of whakapapa trace connections back to land areas, mountains, rivers, lakes, seas and burial grounds. These tracings are essentially acknowledging the land and water that sustained a group of people, becoming markings of identity to locating an individual and his or her ancestral connections to a place or places. Within this study, almost all participants introduced themselves in the interviews by acknowledging their ancestral connections to their particular lands and waterways from where their ancestors derived.

\section{Participant response: Connection to the land}

There's nothing like coming home you know, physically being on the land, physically being and meeting people and that adds to the whole experience, you can only get so much virtually. Well nothing's too hard, you know if the pull's there and the want is there

- Ngaruahine Rangi case study participant

Like a feather plume worn in the hair or an appropriately inscribed moko, one's connections to their lands and waterways are a marking of identity. These ancestral connections to land and water and their contemporary expression depict the immense importance of connection that Māori practice.

\section{Marae and hapū activities and iwi links}

"The marae is the focal point of Māori culture and communal activities [...] it was a courtyard, the plaza and meeting-place" (Walker 1992, 15), and its inhabitants are families and extended family that derive from a main or prominent ancestor; these groupings are 
known as hapū. The majority of marae are rurally based on the ancestral homelands of its ancestors and continue to do so as a place for its descendants to use and access. Urbanisation and pepper-potting has caused urban marae to be established as focal points for Māori (pan-tribal) to belong to and use. However, the cost and time to return back to ones marae to participate in marae and hapū activities is limiting many Māori families, particularly those who live at a distance from their marae.

Marae, hapū and iwi Facebook pages have been created by some of these institutions as ways to connect more to their constituents, and to have access to more of the youth who frequent SNS spaces. Having access to marae, hapū, and iwi is empowering rangatahi Māori with the tools to be updated, kept informed and get involved in activities and events.

Participant response: Connection to marae, hapū, iwi, Māori community
groups
With these smaller marae and hapū a lot of these Māori communities are
realising that rangatahi are on Facebook and so to bring the rangatahi
home back into the marae they are using Facebook as a tool to tell the
world there is a wānanga [workshops] this weekend - come along and
jump in and get involved. Marae, hapū and iwi are really tapping in and
thinking strategically about Facebook and how they can use it and bring
rangatahi in.
- Sonia, focus group participant

This participant, at the time of interview, lived in central Auckland, yet their involvement in what is happening within their marae, hapū, and iwi was steady, as they were made aware of happenings through the Facebook page.

Further, the institutions themselves realised that being accessible through new technologies such as SNS provided access to an important demographic (that is, 18-30 years) of the marae, hapū, or iwi constituency and that it is important to be part of the SNS community to increase the network of the organisation and have greater connectivity amongst its collective.

Participant response: Connection Māori communities
Facebook [has] become the marae of the young people, that's their marae.
That's what Facebook is. It's the marae where they can meet one another
and kōrero [discuss/talk] to each other. Once they get to pahake status like
us, there'll be a yearning to go home, but while they have the ability to
catch one another on Facebook and kōrero to each other, that's where
they're going
- Ngaruahine Rangi case study participant

This tribal organisation speaks about SNS as vital to their communication with hapū members in order to provide up to date information in real time. Not only were users seeking information about what is happening on the marae, activities, hui, gatherings, and hapū/iwi developments, but they also sought these groups as a way to feel a belonging and connection to home, to the marae, to the elders and families who continue to run the marae and therefore, a connection to their cultural identity. 
Safe places for expressing Māori identity are no longer relegated to homes or traditional spaces of gathering such as the marae. SNS are providing this opportunity to Māori from anywhere in the world and it is clear from the data that Māori identity is promoted, encouraged and celebrated in these particular collective spaces enabling users to feel comfortable to expressing themselves as Māori. These online communities are often reflective of Māori social structures such as the marae, hapū, and iwi. However online communities were also being formed outside of traditional social structures of which Māori identity continued to be expressed, articulated and debated (Goodwin 2011).

\section{Conclusion}

SNS is providing another means of communication, another platform and forum in which Māori identity is being expressed, articulated, and formed. What is interesting in this study is the detailed research-based knowledge on the formation or construction of Māori identity from non-traditional spaces. The Internet age is changing these dynamics, enabling Māori to find this information and express their identity through SNS.

This raises some important questions concerned around how information and knowledge of Māori identity is transferred and disseminated. Despite some participants commenting that they continue to engage in their marae, there remains a growing concern amongst communities who tend to the marae and who live within the tūrangawaewae that some Māori whānau are leaving their tribal lands and not necessarily returning. Further queries are raised around the practical impacts on our marae if Māori are accessing intrinsic tribal knowledge from sources other than the marae and what is lost when that knowledge is accessed through means other than oral transmission. Furthermore and importantly, considering this research and the role of SNS on identity formation and articulation, broad considerations must be made with regards to the dislocation of Māori who do not physically frequent the marae and their tribal lands and the flow on effects from that.

The research illustrates the positive impacts to Māori (as presented in this paper) who are able to express, articulate and learn more about their Māori identity online. This research and the queries that have further arisen from the study have provoked further thought in how Māori identity and SNS can be theorised as to what the issues, challenges, and positives are, or as Wall puts it, to explore the possibilities of what being a Māori is and can be.

To move beyond the (re)formation of Māori identity through stereotypes, there should be a retheorisation of difference in ways which re-create it... Rather than promoting an exclusive cultural geography of Aotearoa/New Zealand which defines what being a Māori should be, we need to acknowledge and explore the infinite possibilities of what being a Māori is $\ldots$ and can be (Wall 1997, 44).

Essentially, this argument draws on the complexities in which traditional and contemporary spaces and sources of knowledge that make up Māori identity are being addressed, understood, theorised, and practiced. What is important is the continuation, perseverance, and celebration of Māori identity - regardless of where (the space) or how (the method) it is being expressed and acknowledging that the cultural markers drawn from THNR are a guide to what makes up Māori identity as according to the participants of this study; but undoubtedly for other Māori, cultural indicators far exceed what THNR provides in their framework and these indicators will be more or less important for varying groups of Māori from diverse geographical locations, ages, and backgrounds.

The research is telling us that Māori identity is an articulation from the self, and is supported and affirmed by the collective. Māori identity is an evolving and dynamic fluid process of self-realisation and discovery of the individual grounded in multiple cultural forms from 
diverse local and international locations. It is indeed a journey that the individual embarks on from infancy to create, transform and build their identity as they navigate through teachings, learning's, life, and experiences.

It is abundantly clear that SNS is aiding and assisting Māori users to access more information about their whakapapa, language, performing arts, marae, hapu, and iwi. It is also providing a space in which to express connections to these identity markers by using and learning te reo in SNS, by learning more and engaging with kapa haka and by making connections with new and existing familial relations through SNS

\section{References}

Acquisti, A., and R. Gross. 2006. "Imagined communities: awareness, information sharing, and privacy on the Facebook." In Privacy enhancing technologies, edited by G. Danezis and P. Golle, 36-58. Springer, Berlin, Heidelberg.

http://link.springer.com/content/pdf/10.1007\%2F11957454_3.pdf

Māori Television Services Act (Te Araratuku Whakaata Irirangi Māori). 2003. Accessed May 3, 2013

http://www.legislation.govt.nz/act/public/2003/0021/latest/DLM193696.html.

Anon. 2012. "Te Mana o te Reo Māori." Facebook. Accessed October 3, 2012

http://www.facebook.com/groups/temanaotereo

Attride-Stirling, J. 2001. "Thematic networks: an analytic tool for qualitative research." Qualitative Research 1(3): 385-405. Accessed March 9, 2012

http://qrj.sagepub.com/cgi/doi/10.1177/146879410100100307 [

Benton, R.A. 1987. "From the Treaty of Waitangi to the Waitangi Tribunal." In Living languages - bilingualism and community languages in New Zealand, edited by W. Hirsh, 63-73. Auckland: Henemann.

Biggs, B. 1989. "Humpty Dumpty and the Treaty of Waitangi." In Waitangi Māori and Pakeha perspectives of the Treaty of Waitangi, edited by I. H. Kawharu. Auckland: Oxford University Press.

Bishop, R. 1996. Whakawhanaungatanga: Collaborative stories as Kaupapa Māori research. Palmerston North: Dunmore Press.

Borell, B. 2005. "Living in the city ain't so bad: Cultural diversity of South Auckland Rangatahi." Masters diss., Massey University, Auckland.

Boyatzis, R. 1998. Transforming qualitative information; Thematic analysis and code development. California: Sage.

Braun, V., and V. Clarke. 2012. "Thematic Analysis." In APA Handbook of research methods in psychology, edited by $\mathrm{H}$. Cooper, 55-71. Washington, DC: American Psychological Association.

Cram, F. 1992. "Ethics in Māori research." Working paper, Department of Psychology, University of Auckland.

Durie, A. 1997. "Te Aka Matua - Keeping a Māori identity." In Mai i Rangiatea: Māori wellbeing and development, edited by P. Te Whaiti, M. McCarthy, and A. Durie,142-162. Auckland: Auckland University Press.

Durie, M.H. 1995a. "Te Hoe Nuku Roa framework: A Māori identity measure." Journal of Polynesian Society 104(4): 461-470. 
Durie, M.H. 1995b. "Tino Rangatiratanga: Self determination." He Pukenga Korero 1(1): 44-53.

Durie, M.H. 1997. "Whanau, Whanaungatanga and healthy Māori development." In Mai $i$ Rangiatea: Māori wellbeing and development, edited by P. Te Whaiti, M. McCarthy, and A. Durie, 1-24. Auckland: Auckland University Press, Bridget Williams Books.

Durie, M.H. 1998. Te mana, te kāwanatanga: The politics of Māori self-determination. Auckland: Oxford University Press.

Gibbons, S., A. Temara, and T. White. 1994. "The Māori organisation - A case study." Unpublished report, University of Waikato, Hamilton.

Gibson, K. 1999. "Māori women and dual ethnicity: Non-congruence, "passing" and "real Māori"." In Māori and psychology: research and practice - The proceedings of a symposium sponsored by the Māori and Psychology Research Unit, edited by N. Robertson. Hamilton: Māori and Psychology Research Unit.

Goodwin, I. 2011. "Power to the people? Web 2.0, Facebook and DIY cultural citizenship in Aotearoa New Zealand." New Zealand Journal of Media Studies 12(2): 110-134.

Hiroa, T.R. 1982. The Coming of the Māori. Wellington: Māori Purposes Fund Board.

Te Hiwi, E. 2008. "Disrupted Spaces: Racism and the lived experience of Māori identity formation." In Claiming Spaces: Proceedings of the 2007 National Māori and Pacific Psychologies Symposium 23-24 November 2007, edited by Michelle Levy, Linda Waimarie Nikora, Bridgette Masters-Awatere, Mohi Rua, and Waikaremoana Waitoki, 12-18. Hamilton: Māori and Psychology Research Unit, University of Waikato.

Hoadley, C. M., H. Xu, J. Lee, and M. Beth.2009. "Electronic commerce research and applications privacy as information access and illusory control: The case of the Facebook news feed privacy outcry." Electronic Commerce Research and Applications 1-11. doi:10.1016/j.elerap.2009.05.001

Hohaia, T.M., G. O-Brien, and L. Strongman, eds. 2001. Parihaka: The art of passive resistance. Wellington: Victoria University Press.

Jones, H., and H. Soltren. 2005. "Facebook: Threats to privacy." 1-76. http://groups.csail.mit.edu/mac/classes/6.805/student-papers/fall05-papers/facebook.pdf.

Kāretu, T. 1990. "The Clue to Identity." New Zealand Geographic 5 Jan/Mar: 112-117.

Kāretu, T. 1993. "Toku Reo Toku Mana." In Te Ao Marama 2, edited by W. Ihimaera. 222229. Auckland: Reed Books.

Kawharu, I.H. 1989. Waitangi: Māori and Pakeha perspectives of the Treaty of Waitangi. Auckland: Oxford University Press.

Keegan, T.T. 2000. "Tikanga Māori, Reo Māori ki te Ipurangi: Māori culture and language on the internet."

www.cs.waikato.ac.nz/ tetaka/PDF/TikangaMaori.pdf.

Kennedy, V. 2010. "Social network analysis and research with Māori collectives." MAI Review 3:21.

Kukutai, T. 2004. "The problem of defining an ethnic group for public policy: Who is Māori and why does it matter?" 23:86-108.

Lemon, R. 2001. "The Impact of new media on Māori culture and belief systems." www.aut.ac.nz/resources/research/research_institutes/ccr/ruth_lemon.pdf. 
Matamua, R. 2006. "Te Reo Paho: Māori radio and language revitalisation." PhD diss., Massey University, Palmerston North.

Matthews, K.A.Y.M., and K. Jenkins. 1999. "Whose country is it anyway? The construction of a new identity through schooling for Māori in Aotearoa/New Zealand." History of Education 28(3): 339-350.

Mclntosh, T. 2005. "Māori identities: Fixed, fluid, forced." In New Zealand identities: Departures and destinations, edited by J. H. Liu, T. McCreanor, T. McIntosh, and T. Teaiwa: 38-51. Wellington: Victoria University Press.

Mckinley, E., P.M. Waiti, and B. Bell. 1992. "Language, culture and science education." International Journal of Science 14(5): 579-595.

McRae, J. 1997. "Māori use of writing and print to 1900." In Book and Print in New Zealand: A Guide to print culture in Aotearoa. Wellington: Victoria University Press.

http://nzetc.victoria.ac.nz/tm/scholarly/tei-GriBook-_div3-N1082E.html.

Mead, H.M. 2003. Tikanga Māori. Wellington: Huia Publishers.

Moeke-Pickering, T. 1996. "Māori Identity Within Whānau: A review of literature." http://researchcommons.waikato.ac.nz/bitstream/handle/10289/464/content.pdf?sequence $=1$.

Moewaka Barnes, H. 2008. "Arguing for the spirit in the language of the mind: A Māori practitioner's view of research and science." PhD diss., Massey University, Auckland.

Moewaka Barnes, H. 2000. "Kaupapa Māori: explaining the ordinary." Pacific Health Dialogueialogue 7(1): 13-6.

http://www.ncbi.nlm.nih.gov/pubmed/11709875.

Morehu, C. 2009. "Language re-vitalisation and cultural transformation." MAl Review, 1(Article 8): 1-12.

http://web.its.auckland.ac.nz/ojs.review.mai.ac.nz/index.php/MR/article/viewFile/183/231.

Muhamad-Brandner, C. 2010. "Exploring the cyber-rohe. Māori identity and the internet." PhD diss., University of Auckland.

Ngaha, A. 2011. "Te Reo, a language for Māori alone? An investigation into the relationship between the Māori language and Māori identity." PhD diss., University of Auckland.

Niezen, R. 2005. "Digital Identity: The Construction of Virtual Selfhood in the Indigenous Peoples' Movement." Comparative Studies in Society and History 47(03): 532-551. http://dx.doi.org/10.1017/S0010417505000241.

Orange, C. 2011. The Treaty of Waitangi. 2nd ed. Wellington: Bridget Williams Books Limited.

Pewhairangi, S. 2002. "Internet safety and Māori." In Paper presented at the NetSafe: Society, Safety and the Internet Conference, Auckland, 139-144. www.cs.auckland.ac.nz/ john/NetSafe/Pewhairangi.pdf.

Rangihau, J. 1977. "Being Māori." In Te Ao Hurihuri: The world moves on: Aspects of Māoritanga, edited by M. King: 183-190. Wellington: Hicks Smith.

Robson, B., and P. Reid. 2001. "Ethnicity Matters: Māori Perspectives." In Review of the Measurement of Ethnicity in Official Statistics - Māori Perspectives Paper for Consultation. Wellington: Te Ropu Rangahau Hauora a Eru Pomare. 
Sheehan, M. 2011. "Developing internet protocol television and future broadcasting platforms: A literature review." Te Kaharoa, 4. http://tekaharoa.com/index.php/tekaharoa/article/view/85/52.

Smith, A., and R. Sullivan. 1996. "Māori electronic information: Issues and resources." New Zealand Libraries, 48(6): 111-118.

Smith, G.H. 1997. The development of kaupapa Māori: Theory and praxis. PhD diss., University of Auckland, Auckland.

Smith, J., and S. Abel. 2008. "Ka Whawhai Tonu Mātou: Indigenous television in Aotearoa / New Zealand." Journal of New Zealand Studies 11(1): 1-14.

Smith, L.T. 1999. Decolonizing methodologies. Dunedin: Otago University Press.

Smith, Philippa, Andy Gibson, Charles Crothers, Jennie Billot, and Allan Bell. 2011. World internet project New Zealand: The internet in New Zealand 2011. Auckland: Institute of Culture, Discourse and Communication, AUT University.

https://internetnz.net.nz/sites/default/files/workstreams/worldinternetprojectnz_2011final.pdf.

Spolsky, B. 2003. "Reassessing Māori regeneration." Language in Society 32(04): 553578. Accessed May 18, 2013

http://www.journals.cambridge.org/abstract_S0047404503324042

Stevenson, B. 2004. "Te Hoe Nuku Roa: A measure of Māori cultural identity." He Pukenga Korero 8(1): 37-45.

Tomlins-Jahnke, H. 2002. "Towards a secure identity: Māori women and the home-place." Women's Studies International Forum 25(5): 503-513.

http://linkinghub.elsevier.com/retrieve/pii/S0277539502003138.

Walker, R. 2004. Ka Whawhai Tonu Mātou: Struggle without end. Auckland: Penguin Books.

Walker, R. 1992. "The relevance of Māori myth and tradition." In Te Ao Hurihuri: Aspects of Māoritanga, edited by M. King: 171-184. Auckland: Reed.

Westling, M. 2007. "Expanding the public sphere: The impact of Facebook on political communication."

http://www.thenewvernacular.com/projects/facebook_and_political_communication.pdf.

Williams, H.W. 2006. Dictionary of the Māori Language. 7th ed. Legislation Direct.

Wyche, S.P., S.Y. Schoenebeck, and A. Arbor. 2013. "Facebook is a luxury: An exploratory study of social media use in rural Kenya.

http://yardi.people.si.umich.edu/pubs/Yardi_FacebookLuxury13.pdf. 